Bond University

Research Repository

\title{
Abandoning identity protection for juvenile offenders
}

\author{
Chappell, Duncan; Lincoln, Robyn
}

Published in:

Current Issues in Criminal Justice

Licence:

CC BY-NC-ND

Link to output in Bond University research repository.

Recommended citation(APA):

Chappell, D., \& Lincoln, R. (2007). Abandoning identity protection for juvenile offenders. Current Issues in Criminal Justice, 18(3), 481-487. http://www.austlii.edu.au/cgi-bin/viewdoc/au/journals/CICrimJust/2007/7.html

\footnotetext{
General rights

Copyright and moral rights for the publications made accessible in the public portal are retained by the authors and/or other copyright owners and it is a condition of accessing publications that users recognise and abide by the legal requirements associated with these rights.
}

For more information, or if you believe that this document breaches copyright, please contact the Bond University research repository coordinator. 


\section{Bond University}

\section{ePublications@bond}

$3-1-2007$

\section{Abandoning identity protection for juvenile offenders}

Duncan Chappell

Robyn Lincoln

Bond University, Robyn_Lincoln@bond.edu.au

Follow this and additional works at: http://epublications.bond.edu.au/hss_pubs

Part of the Social Control, Law, Crime, and Deviance Commons

\section{Recommended Citation}

Duncan Chappell and Robyn Lincoln. (2007) "Abandoning identity protection for juvenile offenders" Current Issues in Criminal Justice, 18 (3), 481-487.

http://epublications.bond.edu.au/hss_pubs/237 


\section{Current Issues in Crime and Criminal Justice Contemporary Comment}

\section{Abandoning Identity Protection for Juvenile Offenders}

\section{Duncan Chappell \& Robyn Lincoln ${ }^{1}$}

\section{March 2007}

\footnotetext{
${ }^{1}$ Professor, Acting Director Institute of Criminology, University of Sydney, Duncan.Chappell@usyd.edu.au and Assistant Professor, Criminology, Bond University, rlincoln@staff.bond.edu.au. Address for correspondence: Professor Duncan Chappell, Institute of Criminology, Sydney University Law School, 173-175 Phillip Street, Sydney NSW 2000.
} 


\section{Unprecedented media application}

In what is believed to be a case without precedent in Australia the media organisation, John Fairfax Pty Ltd, publishers of the Sydney Morning Herald and The Age newspapers, recently made application in the NSW Court of Criminal Appeal (NSWCCA) to have a name suppression order removed on two juveniles and their cooffending adult siblings. ${ }^{2}$ The prohibition on publishing their names meant that they could only be known by pseudonyms, namely their initials, on the premise that the naming of the adult brothers would automatically identify the younger ones. In a unanimous decision the NSWCCA (Spigelman CJ, Basten JA and Hislop J) rejected the application on jurisdictional grounds. The decision rested on the fact that current NSW legislation generally empowers a court to grant publication of identity only at the time of sentencing by the sentencing court (NSWCCA 2006).

As all legal proceedings are now exhausted in this matter, the court refused the application by Fairfax stating: 'it is at the time of sentence that the Court reviews the objective gravity of the offence, considers the impact on victims, assesses the weight to be given to general deterrence, acquires the full range of evidence about the subjective features of the offender and assesses the prospects of rehabilitation’ (NSWCCA 2006:para 16). In announcing this decision Spigelman CJ nevertheless remarked that 'the heinous nature of the systematic course of conduct indicates that this is an appropriate case in which the additional element of public shaming could fulfil the function of retribution and also the function of general deterrence that criminal sentences are designed to serve. There may well be a strong case for the exercise of the discretion under s11(4B) of the [Children's (Criminal Proceedings Act) 1987], on the basis of the test set out in s11(4C)' (NSWCCA 2006:para 9).

\footnotetext{
${ }^{2}$ This piece is drawn from material expressed in an opinion by Duncan Chappell presented on 30 October 2006, on behalf of the defendants, to the Court of Criminal Appeal in the application by John Fairfax Publishing Pty Limited v MMK, MRK and others.
} 
While unsuccessful, the application by Fairfax raises important public policy issues and highlights some recent changes to laws and practices around the country concerning protections for juvenile offenders. This comment will address issues of the role of shaming, community protection and prospects of rehabilitation. Before considering each of these factors it is important to place this case in a broader context which takes account of the national and international principles applicable to the treatment of young offenders. Further, the case needs to be seen in its contemporary social and political context in which significant community concerns are being voiced about juvenile crime, and especially sexual assault committed by ethnic groups.

\section{Suppression order cases}

A series of rape offences occurred in mid-2002 in Sydney against four female victims aged from 13 to 17 years, by four brothers plus an adult friend (RS). At the time of the offences, two of the brothers (MSK and MAK) were adults aged 23 and 21 years; and two of them (MMK and MRK) were aged 16 and 17 years. The offenders provided an alibi of another brother but this was rejected, and none of the offenders made a successful case of consensual sexual intercourse. The young men also claimed they had a dysfunctional family in Pakistan, prior to their emigration to Australia, in which they experienced considerable violence and regular abuse. It is alleged that all brothers pleaded their innocence and were said to show little shame or remorse.

The sexual assaults included physical injuries and threats of violence to the victims, and the juvenile offenders, in particular, were deemed to have refused to render assistance or were implicated in the procurement of the victims. The charges included multiple counts of aggravated sexual intercourse, aggravated sexual assault and aggravated kidnapping. In separate trials in late 2003 they were convicted or 
plead guilty, with sentencing in early 2004; although on 14 April RS was to die in tragic circumstances. The offenders were ranked by culpability: MSK and MMK had used knives on the victims; RS and MAK committed one offence each; and MRK was guilty of not preventing the offences and holding one of the victims down during the assault. MSK and MMK were sentenced to 22 years imprisonment, MAK to 16 years and MRK to 10 years. In two other rape cases three of these offenders (MSK, MAK and MMK) were found guilty of a range of charges and were given additional periods of incarceration with parole eligibility dates in the distant future, except for MRK who could potentially be released later this year (R v MAK et al 2003; R v MSK et al 2004; R v MMK 2005).

This case has already generated massive media coverage ranging well beyond the borders of NSW. It is coverage which has revealed extensive details about the ethnic, religious and family backgrounds of the offenders, gleaned from their public trials. In addition a best-selling book, written by a senior Fairfax columnist, has been partially serialised (Sheehan 2006). The scope and content of this publicity has now made it part of the ongoing and increasingly intense national public debate about ethnic crime and especially sexual assault. For example, reference was made to the case on the front page of The Australian in reporting remarks made by the Muslim cleric, Sheikh Taj Din al-Hilali (Kerbaj 2006). The article included comments made by two of the victims, as well as the following:

For legal reasons the brothers who raped Ms Wagner and Ms Hamim cannot be named, because two of them were under the age of 18 when the crimes were committed. The girls have willingly given up their anonymity saying that they do not feel ashamed of being victims. ... The gang of brothers and their friends raped and violated young Australian girls over a period of some months, filming some of the attacks. ... During their trial some of them leered at the girls and mocked their suffering. ... One of the rapists told the court that he had been raised in a Pakistani village where he was taught that it was OK to rape women who went outside without a veil, or entered a man's home without a chaperon. 
As with most media coverage, certain inaccuracies exist in the facts alleged in this comment, but it does reveal the level of contemporary public knowledge and interest in the case.

\section{Recent efforts to abandon protection for juveniles}

The 'law and order' platform has been widely invoked by politicians in their election campaigns, including that which resulted ultimately in the removal from the NSW Children’s (Criminal Proceedings) Act 1987 of the total prohibition on the publishing and broadcasting of the names of young offenders. ${ }^{3}$ Similar campaigns to 'name and shame' young persons convicted of crimes have been witnessed in other jurisdictions in recent years. In the Northern Territory there are now few prohibitions to prevent young offenders being identified — a complete reversal of the situation which prevailed for decades under statutory law (Carrick 2006). In Queensland during recent elections the Coalition planned to make it mandatory to publicly name any juvenile aged 14 and over convicted of a serious crime but allowing a court to suppress the name in 'exceptional circumstances' (Queensland Coalition 2006). The proposed law was said, by party leaders, to mean that juveniles who commit heinous crimes would no longer be able to live a 'life of anonymity'. The Coalition was defeated at the election, resulting in the existing provisions, similar to those in $\mathrm{s} 11(4 \mathrm{~B} / \mathrm{C})$, remaining in place.

When first introduced Section 11 of the NSWCCPA 1987 undoubtedly reflected the values and principles now enshrined in international conventions. While

\footnotetext{
${ }^{3}$ Section 11(4B/C) states: ‘(4B) A court that sentences a person on conviction for a serious children’s indictable offence may, by order made at the time of sentencing, authorise the publication or broadcasting of the name of the person (whether or not the person consents or concurs). (4C) A court is not to make an order referred to in subsection (4B) unless it is satisfied (a) that the making of such an order is in the interests of justice, and (b) that the prejudice to the person arising from the publication or broadcasting of the person's name in accordance with such an order does not outweigh those interests.'
} 
it is a fundamental principle of the rule of law that justice should be administered in an open and transparent way, exceptions to this principle can occur when public policy demands it, as in the case of children. There is a clear public interest in the primacy of rehabilitation for young people and ensuring that this is not compromised through the publication or broadcasting of information about criminal proceedings which involve their participation. The amendments made in 2001 to s11 of the NSWCCPA now permit, in limited circumstances, publication of the names of young offenders, thereby weakening the protections envisaged by international conventions.

\section{Revisiting those international protections}

Measures like those above run counter to well-established international principles protecting the rights of young people involved in the criminal justice system, including the United Nations Convention on the Rights of the Child which Australia ratified in December 1990. ${ }^{4}$ This Convention is incorporated into federal law as a part of the human rights responsibilities of the Human Rights and Equal Opportunity Commission. The Convention recognises that children, 'by reason of (their) physical and mental immaturity, (need) special safeguards and care, including appropriate legal protection'. Article 16 of the Convention protects children from arbitrary interference with their privacy, and Article 40 states that youthful offenders must be treated in a manner 'which takes into account the child's age and the desirability of promoting the child's reintegration and the child's assuming a constructive role in society’. In addition, the United Nations Standard Minimum Rules for the Administration of

\footnotetext{
${ }^{4}$ UN Convention on the Rights of the Child, A/RES/44/25, 20 November 1989. We are indebted to the Public Interest Advocacy Centre (PIAC) for making available a copy of a submission made to the NSWLRC, dated 17 October 2006, in regard to a Privacy reference currently before the Commission. The submission, prepared jointly with the Shopfront Youth Legal Centre, contains a number of valuable observations about the operation of s11 of the NSWCCPA 1987 including mention of the Convention principles.
} 
Juvenile Justice (the Beijing Rules) render severe restrictions on 'the publication of any information which would allow the identification of youths found guilty of a criminal offence in the juvenile jurisdiction’ (Cunneen \& White 2002:276).

\section{Consequences of abandoning protection}

The changes wrought by the dilution of protections in the Northern Territory and those now available under s11(4B/C) in New South Wales are predicated on the view that publicly naming juveniles will yield a semblance of shame to offenders. Indeed, Spigelman CJ offered this as a possible rationale for a sentencing court to exercise its discretion to lift a suppression order. The Chief Justice referred in particular to the role which naming and shaming juvenile offenders might play in fulfilling the sentencing objectives of retribution and general deterrence. We turn now to consider the criminological evidence relevant to these particular issues.

The push to name and shame appears to be modelled around principles of restorative justice and the reintegrative theory that underlies it (Braithwaite 2002). Yet, restorative justice transactions, when they occur in well-established programs like those operating in South Australia, New Zealand and NSW, require carefully planned and controlled management of the interactions between the parties involved. They are not the type of transaction carried out in public fora, nor do they require the public identification of any parties in order to reach an agreement about how best to make amends. Available research suggests that stigmatising shaming is likely to have negative rather than positive rehabilitating outcomes (Sherman 1993; Strang 2002) and indicates that victims of crime prefer a reintegrative approach, even in sexual assault cases (Strang 2002; Daly 2006). 
There is also an underlying assertion, by those who advocate the public naming of juveniles, that such moves will offer protective benefits to the community. Indeed at the time of the introduction of $\mathrm{s} 11(4 \mathrm{~B} / \mathrm{C})$ community protection was stated to be one of the justifications for the amendment. It is also suggested that the public can be better involved in the supervision of released sex offenders if they know their identities, where sex offender registers or notification provisions are seen as a means of alleviating public fears. It is problematic, at best, whether the desired aim of achieving better community protection from future sex offending is advanced by the naming of offenders. Comparative research suggests that programs to name and shame sex offenders fail to meet their goals and have significant and unintended consequences.

One examination of a range of both public and private notification options for sex offenders concludes that (Ronken \& Lincoln 2003:250):

Naming and shaming are likely to have at least three serious consequences: the identification of the victim with the potential to revictimise him or her; a resulting punishment frenzy among a community; and distortion of any rational discussion in the sex offence and child abuse area. While it is clear that notification offers plenty of shame there is no reintegration of the offender into the community. The offender is more likely to be subjected to harassment and ostracism.

There is every reason to believe that in these rape cases the naming of the offenders may yield such consequences. One result could be elevated risk to the victims, for not all have opted to take the courageous step of identifying themselves and so their anonymity could be prejudiced by information that reveals the identity of their attackers.

Another distinct, rather than remote, consequence is that of vigilante action against the offenders, especially given the massive media coverage their crimes have garnered. Attacks have already occurred against two of the offenders and as a result 
both are being detained in protective segregation (NSWSC 2006:para 91). More recently two of the brothers were 'set upon by six prisoners' at Goulburn gaol with one suffering serious head injuries (Kearney 2007). While no attacks appear to have been committed against the two juvenile offenders, they remain at risk, especially once transferred to adult correctional facilities. This is most likely to affect MMK whose sentence and non parole period mean that he will serve many years in adult prison. However, MRK becomes eligible for parole in late 2007 and thus there is a more immediate possibility of community vigilante action.

Although not directly addressed by Spigelman CJ, the naming and shaming of juvenile offenders can have an impact on another paramount sentencing objective, namely rehabilitation. This impact requires examination as it relates particularly to the two then-juvenile offenders. The background is that those who advocate public naming imply that such 'outing' is an essential step in accepting culpability and thereby achieving rehabilitative ends. Relevant research, in particular two comprehensive Australian-based overviews which assess the state of our knowledge about recidivism and the effectiveness of various sex offender treatment programs (Lievore 2004; Chung et al 2006) suggest that the situation is not as bleak for the rehabilitation prospects of sex offenders as many appear to believe. The international literature broadly concurs on several points: including that rates of sexual recidivism are low relative to other offence types; and that sub-groups of sex offenders recidivate at different rates. In regard to sex offender treatment programs a recent meta-analysis showed that treatment programs (mostly based around psychological interventions) can have a positive effect in reducing recidivism.

Our core contention in regard to the naming of MMK and MRK is that their identification will negatively impact upon their successful rehabilitation and their 
prospects of reintegration into the community on release. In realistic terms only MRK is likely to be released in the near future and therefore is of most concern. It is apparent from the detailed review made by the court of MRK's background at the time of his sentencing in April 2004 that Justice Sully felt that MRK should receive every assistance in achieving rehabilitation. Justice Sully noted that for 'all of his ups and downs while in custody' he had successfully completed his HSC while detained at the Kariong Juvenile Justice Centre — 'an achievement of real substance’ (R v MSK et al 2004:para 106). The judge observed that while his offence behaviour was callous and cowardly it was 'nowhere near as bad as that of the actual rapists'. Accordingly some flexibility was justified 'by the need not to snuff out peremptorily the promise shown by MRK in attaining his HSC in such unpromising circumstances' (R v MSK et al 2004:paras 174-5).

One final consequence to note is drawn from the James Bulger murder case in the United Kingdom. This case has continued to generate international publicity following the decision to release on license the two offenders responsible for the killing of a two year old boy. ${ }^{5}$ At the time of the offence both Robert Thompson and Jon Venables were ten years old. Under British law their names were made public following their conviction and sentence. However, in order to protect them from violent threats a court order remained in place throughout their detention prohibiting publication of information that might reveal their whereabouts. A successful prosecution was brought against one British newspaper for breach of this injunction. Further, once the decision was made to release Thompson and Venables were given new identities to protect their personal safety. This case illustrates just how far the

\footnotetext{
${ }^{5}$ A comprehensive bibliography and repository of media and related material about the Bulger case can be found at http://www.guardian.co.uk/bulger/0,192515,00.html.
} 
authorities may have to go in order to afford protection to young offenders once they are named.

\section{Conclusions}

For the above reasons there would likely be a number of detrimental outcomes arising from any disclosure of the juveniles' identities. These include: a misuse of the concept of shaming, the potential for vigilante action, a false sense of community protection, and the possibility of interfering with any rehabilitative efforts. This is especially so at a time when MRK — sentenced as a juvenile and in accord with the principles of the Convention — is on the cusp of potential release. The movement to publicly name juvenile offenders is clearly gathering momentum and demonstrates that long-held protections for youthful offenders, and the international conventions that support them, are slowly being eroded, if not abandoned.

Looking beyond the case of MRK and his brothers the reality remains that many of the protections long afforded to juveniles within the nations's criminal justice system are now under sustained assault. In NSW, for instance, at the time of this comment an election is looming at which the opposition is advancing a 'law and order’ platform including provisions to remove the so-called principle of doli incapax 'whereby a child over the age of 7 but under 14 is presumed incapable of wrongdoing' (Bronitt \& McSherry 2005:151), and the introduction of far-reaching anti-social behaviour orders for young people. ${ }^{6}$ Such measures may have strong electoral appeal but they do not, like the Fairfax application, offer any guarantee of enhancing community safety or improving the rehabilitation prospects of young offenders.

\footnotetext{
${ }^{6}$ See Sydney Morning Herald articles available at http://www.smh.com.au/news/law-and-order/make10yearolds-responsible-for-crimes-debnam/2007/03/02/1172338805053.html or http://www.smh.com.au/news/NATIONAL/Debnam-pledges-600-more-policeofficers/2007/03/04/1172943262802
} 


\section{References}

Braithwaite, J (2002) Restorative Justice and Responsive Regulation, Oxford University Press, New York.

Bronitt, S and McSherry, B (2001) Principles of Criminal Law, LBC Information Services, Sydney.

Carrick, D (2006) Naming and Shaming Juvenile Offenders, ABC Radio National Law Report, 3 October, available at www.abc.net.au/rn/lawreport/ stories/2006/1752189.htm.

Chung, D, O’Leary, PJ \& Hand, T (2006) Sexual Violence Offenders: Prevention and Intervention Approaches, Australian Institute of Family Studies, Melbourne.

Cunneen, C \& White, R (2002) Juvenile Justice: Youth and Crime in Australia, Oxford University Press, Melbourne.

Daly, K (2006) 'Restorative Justice and Sexual Assault: An Archival Study of Court and Conference Cases’, British Journal of Criminology, vol 46, pp 334-356.

Kearney, S (2007) Surgery for Gang Rapist after Jail Yard Bashing, The Australian, 10 February.

Kerbaj, B (2006) Mufti Outrages His People, The Australian 27 October, 1 \& 4.

Lievore, D (2004) Recidivism of Sexual Assault Offenders: Rates, Risk Factors and Treatment Efficacy, Australian Institute of Criminology, Canberra.

NSWCCA (2006) Judgement in the Application by John Fairfax Publications Pty Ltd re MSK, MAK, MMK and MRK [2006] NSWCCA 386.

Queensland Coalition Policy \#085,available at http://qldcoalition.org.au/policy.aspx

$R$ v MAK; $R$ v Ram Chandra Shrestha; $R$ v MSK; $R$ v MRK; $R v$ MMK (2003) NSWSC 849.

$R v M S K ; R \vee M A K ; R v M R K ; R v M M K(2004)$ NSWSC 319

Ronken, C \& Lincoln, R (2001) 'Deborah’s Law: The Effects of Naming and Shaming on Sex Offenders in Australia', The Australian and New Zealand Journal of Criminology, vol 34, no 3, pp 235-255.

Sheehan, P (2006) Girls Like You: Four Young Girls, Six Brothers and a Cultural Timebomb, Pan Macmillan, Sydney.

Sherman, L (1993) 'Defiance, Deterrence and Irrelevance: A Theory of the Criminal Sanction', Journal of Research in Crime and Delinquency, vol 30, pp 445-473.

Strang, H (2002) Repair or Revenge, Clarendon Press, Oxford. 